\title{
Born to flip. Exit decisions of entrepreneurial firms in high-tech and low-tech industries
}

\author{
Elena Cefis • Orietta Marsili
}

Published online: 5 January 2011

(C) The Author(s) 2011. This article is published with open access at Springerlink.com

\begin{abstract}
This paper examines the way that the exit behavior of entrepreneurial firms is shaped by their innovative capabilities, and the technology environment in which they operate. We distinguish between exit by closing down activity and exit by merger or acquisition (M\&A). Using a large sample of Dutch manufacturing firms, we explore the relationship between firm exit, age and innovative capabilities, in high and low innovation intensive industries. We find that for entrepreneurial firms, innovation may go some way towards compensating for the liability of newness, but also makes them more attractive M\&A targets. More specifically, entrepreneurial firms in high-tech industries do not seem to improve their chances of survival by innovating; when technological change is rapid, innovation, especially in products, is necessary to participate in the innovation race in an industry, but is not sufficient to guarantee survival. In contrast, in low-tech industries, process innovation is a critical condition for the survival of entrepreneurial firms. In this context, entrepreneurial firms that are able to bring new product ideas, introducing 'exceptional'
\end{abstract}

\footnotetext{
E. Cefis

Dep. of Economics, University of Bergamo, via dei Caniana 2, 24127 Bergamo, Italy

e-mail: elena.cefis@unibg.it

E. Cefis

Utrecht School of Economics, Utrecht University, Vredenburg 138, 3511 BG Utrecht, The Netherlands

e-mail: e.cefis@econ.uu.nl

O. Marsili (凶)

Rotterdam School of Management, Erasmus University, Burg. Oudlaan 50, 3062 PA Rotterdam, The Netherlands

e-mail: omarsili@rsm.nl
} 
variations into a stable environment, are most likely to exit by $\mathrm{M} \& \mathrm{~A}$, thereby transferring their knowledge and capabilities to the incumbent firms.

Keywords Mergers and acquisitions • Firm exit • Innovation • Entrepreneurship

JEL Classification $\mathrm{L} 11 \cdot \mathrm{L} 25 \cdot \mathrm{D} 21 \cdot \mathrm{C} 1$

\section{Introduction}

It is a fact that a large proportion of new firms exit within few years of start up. Less than half of start-ups survive more than 5 years after entry, and less than a third survive 10 years after entry. This pattern is fairly consistent among cohorts of firms founded in different years, or located in different countries. The evidence of high exit rates among new firms is supported by a long tradition of studies in Industrial Economics, which have resulted in the 'stylized fact' that the probability of survival increases with firm age (Caves 1998; Geroski 1995). Consistent with this evidence, studies in Organizational Ecology suggest that organizations are subject to the 'liability of newness', and that their hazard of mortality decreases with age. At the same time, case studies and press anecdotes tell of acquisitions of high potential new ventures by established market leaders, indicating that the exit of entrepreneurial firms can be highly successful. Entrepreneurs at various stages of their entrepreneurial careers may decide to sell their companies in order to reap the rewards from their business activity, or in order to move on to another new venture. For example, the participation of venture capitalists in the funding of a new enterprise often imposes constraints on the timing and mode of exit of the company. Indeed, venture backed firms are often created with the expectation of their being sold on to larger firms. Also, entrepreneurs may decide to merge their successful new ventures with established firms, as a way to continue growth that would otherwise be limited by lack of managerial or financial resources. Entrepreneurial firms can follow different paths to exit, which may not necessarily signal failure, but rather may be based on an explicit strategy (Freeman et al. 1983; Headd 2003).

The survival of new firms is related to a number of factors, such as firmspecific resources and capabilities e.g. human capital and knowledge capital, the intensity of market competition, the technology environment, and the macroeconomic conditions (Geroski et al. 2010). It is acknowledged that most empirical studies on survival treat exit as a homogeneous event (often because of data limitations), and fail to capture the differences between the factors that influence the decision to close down the company and those related to the decision to sell it on (Gimeno et al. 1997; Wennberg et al. 2010). These differences are not sufficiently investigated in the literature. Cefis and Marsili (2007) show that innovation plays a role in the general decision of a firm to exit, and the choice of the mode of exit. 
This study contributes to the analysis of the determinants of the exit decisions of entrepreneurial firms, by differentiating between exit by closure and exit by M\&A. The novelty of the paper lies in highlighting the importance of the 'fit 'between the innovative behavior of firms and the technological environment, in which they operate, as a determinant of entrepreneurial exit. Starting from the consideration that young firms suffer the liability of newness, we examine whether this liability differs between forms of exit, and how it is shaped by firm-specific innovative capabilities and the industry-specific rate of technological change. Using a large panel of Dutch manufacturing firms from 1996 to 2003, we estimate a competing risks model, which allows us to compare (within the same framework) the probabilities of exiting by closure and by M\&A, between categories of firms that differ in age (young and old), innovative capabilities (innovators and non-innovators, in products and/or processes), and technological environment (high-tech and low-tech industries).

We find there are two mechanisms at play, which are contingent on the technology environment. First, our results confirm that there is an innovation premium for survival (Cefis and Marsili 2006), which mitigates the liability of newness of entrepreneurial firms, with respect to actual failure or termination of activities by the firm. Second, innovation influences the choice of a possible strategic exit, when entrepreneurs contemplate the alternative between selling the new venture and competing in the market. We observe that by innovating, young firms, in low-tech industries, but not high-tech industries, can improve their chances of success, lowering the risk of closure or increasing the possibility to sell the company. This suggests that in a rapidly changing environment, innovation is necessary, but not sufficient to guarantee the survival of new firms or to create a successful path to exit: the process of competition assumes the characteristics of "Red-Queen" competition (Barnett and Hansen 1996), in which innovation is the entry ticket to the race. Conversely, in a slow changing environment, innovation improves the chances for survival for new firms as well as the option of a successful exit route: when innovation displays exceptionality in the process of competition, innovation becomes the winning ticket.

\section{Theoretical background}

\subsection{Innovation, age and survival}

Evolutionary approaches to industrial dynamics (Nelson and Winter 1982) imply that the reason that some firms survive while others die, is that they have better competencies, which allow them to introduce new products or processes, or they have a better 'environmental fit' because their innovations are more closely aligned to the expectations of the market and the industry (Sorensen and Stuart 2000). Sorensen and Stuart (2000) argue that ageing is an important organizational process that affects both firm competence, specifically its ability to innovate, and the firm's environmental fit. In particular, Sorensen and 
Stuart observe systematic differences in the patterns and value of patents held by old and young firms. They conclude that age makes firms more efficient at innovating, but tends to reinforce existing competencies and local search rather than exploration of new and more distant fields of knowledge. The result is that old firms may lose out to younger firms in term of environmental fit (Sorensen and Stuart 2000).

Although Sorenson and Stuart do not examine firm survival (they focus on the relationship between age and innovation), they suggest that their results have some implications for understanding the link between innovation, age and survival. While innovation generally is perceived as beneficial for firm survival, they argue that this effect may vary with firm age. The finding, in particular, that innovations by older firms are 'less well matched' to the market environment, would indicate that innovation loses its influence on survival as firms age. However, they posit also that older firms may be able to counterbalance this disadvantage, by relying on their stronger reputation and more established networks of relationships with customers, suppliers, competitors and other institutions (Sorensen and Stuart 2000). There is some evidence that the former effect is stronger than the latter. Cefis and Marsili (2006) find that the innovation premium for survival (i.e. the increased probability of survival due to innovation) is higher in young than in old firms, although they do not distinguish between types of exit. Based on these considerations, we expect that innovative capabilities compensate for the liability of newness among entrepreneurial firms in the specific case where exit means the termination of activities.

\subsection{Innovation, age, and exit by M\&A}

Exit though a merger or sell out to an established competitor, is often a viable strategy for firms that want to exploit their growth potential or reap the economic returns of their innovations. Gans and Stern (2003) propose that acquisitions are one particular expression of the functioning of the 'market for ideas'. They highlight that new ventures based on an innovative technology or product, can adopt different strategies to capture economic rents. They can compete in the product market, bringing the innovation to commercial application, or they can trade their idea in the external markets for technology via licensing or strategic partnerships, or selling the entire company to a competitor (Gans and Stern 2003). On the side of the potential buyers, mainly large, established firms, acquisition of an innovative firm provides access to knowledge and capabilities that otherwise might be difficult to develop in house (Coff 1999; Cohen and Levinthal 1990; Ranft and Lord 2002). For a potential seller, innovation enhances the value and visibility of its intangible resources, making the firm a more attractive target for the M\&A process (Cefis and Marsili 2007).

Gans and Stern's (2003) analysis of commercialization strategies is based on new technology-based firms. In fact, the constraints that the commercialization environment imposes on the strategic choices of innovative firms seem to 
be more compelling for young than for old firms. Young firms typically lack legitimacy and resources. They may find it more difficult to protect their new technology from imitation by more established competitors. In order to bring their innovations to market, the access to the specialized complementary assets of potential competitors may be critical. Building these assets in-house requires significant investment in the form of sunk-costs, which young firms often are not able to sustain. Under these conditions, entrepreneurs may prefer not to try to compete directly with established firms, but rather to trade their ideas-including the possibility to sell the entire company-in the market for technology (Gans and Stern 2003).

The argument that an acquisition can be the outcome of a commercialization strategy of a new firm with an innovative idea (Gans and Stern 2003) would seem to apply more to firms with product development rather than process development capabilities. Potential acquirers can detect more easily, and also attach greater value to, product innovations compared to process innovations, when assessing a target firm; also product innovation allows the seller to demonstrate its value with more certainty (Cefis and Marsili 2007). Following this line of reasoning, we argue that innovation strengthens the liability of newness of entrepreneurial firms, when exit is in the form of a M\&A. We expect also that this effect will be stronger in the case of product compared to process innovation.

\subsection{Entrepreneurial exit and the rate of technological change}

We next consider whether the liability of newness is influenced by the nature of the technology environment. Models of industry evolution in the Schumpeterian tradition predict that the likelihood of survival reflects the firm-specific ability to innovate, and the intensity of the market selection mechanism through which the market rewards or penalizes firms on the basis of their 'environmental fit'. Firms whose competencies have a better fit with the environment can expand their marker shares and survive (Dosi et al. 1995; Nelson and Winter 1982; Silverberg et al. 1988). By innovating firms modify their routines or increase the efficiency of existing ones, with the purpose of achieving a better environmental fit. Whether or not this is achieved depends, ex post, on how competing firms adapt to change, and how the distribution of competencies in the population co-evolves with the attempts of the individual firm to improve its fit with the environment. This leads to the argument that, while innovative efforts lower the firm's risk of failure, this effect is conditional on the nature of the environment and, in particular, on how fast the environment is changing as a result of innovative activity in the whole industry.

Two contrasting arguments have been proposed about whether the survival of new firms is favoured by rapidly changing or stable environments (Audretsch 1991; Gort and Klepper 1982; Nelson and Winter 1982; Sarkar et al. 2006; Winter 1984). There is some evidence supporting both positions. There is a strand in the literature that argues that the uncertainty associated with innovation activity, and the sunk-costs of investing in research and 
development (R\&D), which may represent barriers to entry, means that new firms are less likely to survive in high-tech industries (Audretsch and Mahmood 1995; Mahmood 1992). Another strand maintains that the rich pool of technological opportunities enables the successful entry of new firms in high-tech industries, especially when radical new technologies render the competencies of incumbent firms obsolete leaving them locked into existing technological trajectories and outdated business propositions (Agarwal 1996, 1998).

These studies focus on firm survival, regardless of type of exit. However, the nature of the technology environment may have an influence on the mode of exit. Freeman et al. (1983) observe that the patterns and dominant form of exit differ across organizational populations. For example, in the case of two populations of organizations, namely newspaper publishing companies and labor unions, they find that rates of firm dissolution are higher than merger rates and are more dependent on organizational age (i.e. the liability of newness is stronger) in the first population while the opposite is true for the second one. They suggest that these differences may be explained on the grounds of differences in the nature of the resource endowments of the two populations.

While there are numerous studies of industry differences in survival and exit rates, based on the nature of technology, we need also to know how the technology environment influences the choices made by entrepreneurial firms with different innovative capabilities, about mode of exit. Innovation can have a twofold effect: it decreases the likelihood that entrepreneurial firms will exit by closure and increases the likelihood of take over. We suggest that the strength of these effects will depend on the nature of the technology environment. By looking at the interaction between firm age, innovation, and technology and its influence on exit behaviour, we can assess the environmental fit of new firms in relation both to their specific innovative capabilities and to the rate of change in the environment in which they are competing.

\subsection{Control variables}

In the present study we control for a number of factors that may influence exit probabilities. First, we control for the effect of firm size (Freeman et al. 1983). It is a stylized fact that the likelihood of survival increases with firm size, although at a decreasing rate (Geroski 1995), while the probability of being acquired declines with the size of the target firm. We control for the firm's ownership status by distinguishing independent firms from those that belong to a group. One of the arguments advanced in the literature is that new firms that are subsidiaries or branches of a multi-unit firm have better survival prospects than new independent firms, since they can draw on the resources (knowledge, managerial and financial) of parent firms (Audretsch and Mahmood 1995). However, it has also been suggested that firms that are branches and subsidiaries of established firms are more likely to exit than independent new firms, because of the lower 'barriers to exit' (Caves and Porter 1976). The decision of management to close down a subsidiary or branch, especially if 
the parent firm is a highly diversified multi-unit firm, will be easier than the decision of a firm founder to dissolve the company: managers have higher opportunity costs (better alternatives if the unit closes down) and can more easily reallocate resources, especially employees, to other units (Audretsch and Mahmood 1994; Caves and Porter 1976). This increases the unwillingness of managers to cope with low rates of returns from the units they are responsible for (i.e. their 'threshold level of performance' is higher than that of founders/owners of independent ventures) (Gimeno et al. 1997). Audretsch and Mahmood (1995) find some evidence to support this argument. Using the US Small Business Data Base, they observe higher hazard rates for new subsidiaries or branches of multi-unit firms, than for new independent firms.

We control also for differences in exit patterns between Dutch firms and the subsidiaries of multi-nationals located in the Netherlands. The literature on multinational enterprises (MNE) suggests that the performance of foreign subsidiaries depends on the institutional distance (which embraces differences in regulations, norms and cognitive dimensions) between the foreign subsidiary and the host country ( $\mathrm{Xu}$ and Shenkar 2002). This means that there are differences in the conditions of national firms and foreign subsidiaries in relation to survival or strategic exit.

Finally, we take account of the firm's patenting activity. Using patents as a means of protecting innovative ideas from imitation, even if effective for only a limited time period, may help the firm achieve competitive advantage, thus lowering the probability of failure. Also, and especially in situations of information asymmetry, patents signal the quality of an innovative idea and the commitment of the entrepreneur to its development, to external investors or potential buyers. This may lead to contrasting effects. By enhancing the firm's bargaining power in the external markets for resources, such as the financial capital market, patents lower the probability of firm exit. At the same time, in their role as valuable and recognizable assets, patents may make the firm a more attractive target for an M\&A, thereby increasing the probability of strategic exit (Gans and Stern 2003; Teece 1986). Wagner and Cockburn (2010) provide evidence that these different effects can coexist. In a study of delistings from the NASDAQ stock market, of Internet related companies, they observe that, generally, patenting lowers the probability of exit by business failure, while the effect on exit by acquisition is conditional on the value of the patents. Firms with higher numbers of patents are less likely to exit because of an acquisition; however, if their patents are of particularly high value (i.e. they are highly cited), an exit through acquisition becomes more likely.

\section{The data}

This study is based on data from two harmonized and comprehensive microeconomic sets of data on manufacturing firms in the Netherlands collected by the Netherlands Central Bureau of Statistics (CBS): the Annual Business Register $(\mathrm{ABR})$ database and the second Community Innovation Survey (CIS-2). 
Combining these datasets allows us to integrate at firm level data on innovation and demographic events. The ABR database includes all firms registered in the Netherlands for fiscal purposes. It records the month of firm entry to or exit from the register. The comprehensiveness of this register means that these events can be considered close proxies for entries and exits in the market. The ABR database also reports the reason for a firm being delisted. Based on this information, we can distinguish two forms of exit: (i) exit by failure, which includes firms de-listed because of termination of activities; ${ }^{1}$ and (ii) exit by M\&A, which includes a firm merger that results in a new firm with a different identity, and acquisition by another firm, where the acquired firm is de-listed from the register and the acquiring firm maintains its identity. ${ }^{2}$

CIS-2 collected information on innovation activities in the Netherlands for the period 1994-1996. The survey included private sector firms with at least 10 employees. It was administered by CBS to a random sample of firms extracted from those present in the ABR at 1996, and stratified by size class, region and industry sector at the 2-digit standard industry classification (SIC). In manufacturing, the number of CIS-2 respondents was 3,275 firms, a response rate of $71 \%$. We used this dataset to establish whether a firm introduced an innovation in the period 1994-1996, and the type of innovation-product or process.

To achieve compatibility with CIS-2, we considered all manufacturing firms present in the ABR at year 1996, which, including firms with zero employees, that is, self-employment, is 61,177 . From the ABR datasets, we calculated the state of existence and the mode of exit of each firm over the period January 1996 to December 2003. We derived the initial conditions at 1996 in terms of firm age (using date of entry), firm size (measured by number of employees) and sector of activity categorized as low-tech and high-tech. ${ }^{3}$

In order to compare the way innovative capabilities and the technology environment (and their interaction) influence the exit behaviour of entrepreneurial firms compared to established firms, we set an age threshold of 5 years to distinguish between 'young' versus 'old' firms. Using age classes

\footnotetext{
${ }^{1}$ The definition in the dataset of termination of activities does not distinguish between voluntary closure and bankruptcy. However, the two events can be considered equivalent for the purpose of the present analysis, as both represent a form of failure: if it were profitable, a firm would not be disbanded without selling some part of its activities.

${ }^{2}$ We examine the occurrence of an exit by M\&A by focusing on the differences between entrepreneurial firms and established companies being merged or acquired. No similar distinction is made on the side of acquirers, which in this study and in the M\&A literature more generally, are assumed to be established firms.

${ }^{3}$ Firms are assigned on the basis of the SIC code, to high-tech manufacturing or low-tech manufacturing based on the OECD (2001) industry classification. High-tech manufacturing in the present study covers the two OECD categories of High-technology industries and Mediumhigh-technology industries, which include Chemicals \& chemical products, Machinery, Office machinery \& computers, Electrical equipment, Radio, television \& communication equipment, Instruments, Motor vehicles, and Other transport equipment (excl. shipbuilding and repairing).
} 
for young and old firms and the associated dummy variable (entrepreneurial firm), to estimate the competing risks model makes it easier to disentangle the effects of age, in its interaction with firm innovation and technology environment, on the probability of exit. In the entrepreneurship literature, new firms are commonly defined on the basis of a threshold for firm age, although selection of a specific threshold varies across studies. For example, McDougall et al. (2003) contend that firms aged six (e.g. Stearns et al. 1995) (or in some cases 8) years or less can be considered new firms. Some studies apply the lower threshold of 5 years (Bloodgood et al. 1996) while others classify firms as 'young' or 'old' based on thresholds of 6 years (Evans 1987) and 9 years (Bracker and Pearson 1986). Using a cut-off point for age classes should maximize the expected effects of age on exit probability because the conditional effects of covariates can be more easily detected for younger firms compared to the group of old firms. We estimate a multinomial logit model relating exit probabilities to firm age, expressed as a continuous variable in months, and to its square value, controlling for the other variables in the analysis. For both types of exit analysed here, we observe that the predicted $\log$ odds display the greatest variation with respect to firm age within the first 2 years of the firm's establishment, and at 5 years of age, have largely leveled off, and are much less sensitive to firm age variations. ${ }^{4}$ Our choice of a 5-year threshold is consistent with the empirical literature and is quite stringent compared with the thresholds in some other studies. Nevertheless, this threshold is conservative in the sense that in the group of young firms expected to be the most exposed to the risk of exit, there are some relatively older firms which are beyond the liability of newness, which should ensure that the results of the analysis are not affected significantly by small variations in the definitions of age classes.

The proportion of firms surviving throughout the period of observation is higher in CIS-2 than for the whole population in the ABR (77.5\% and $55.0 \%$ respectively). With regard to composition by mode of exit, the percentage of firms that exit by closing down activities is higher in the ABR than in CIS-2 (39.6\% and $11.9 \%$ respectively), while the opposite is true for exit by M\&A (5.0\% and $8.4 \%$ respectively). These differences are due to the threshold of a minimum of 10 employees for CIS-2 firms, and the fact, observed also in this dataset (Cefis and Marsili 2005, 2007), that small firms are less likely to survive than large firms, and relatively more likely to exit by closure than to exit by an $\mathrm{M} \& \mathrm{~A}$

Table 1 displays descriptive statistics and the correlation matrix for the variables used in the analysis. Not surprisingly, the 'innovator' variable is highly correlated to the product innovator and process innovator variables: by definition, a firm is characterized as an innovator if it produces a product innovation or a process innovation. We include these variables separately,

\footnotetext{
${ }^{4}$ Results available on request.
} 


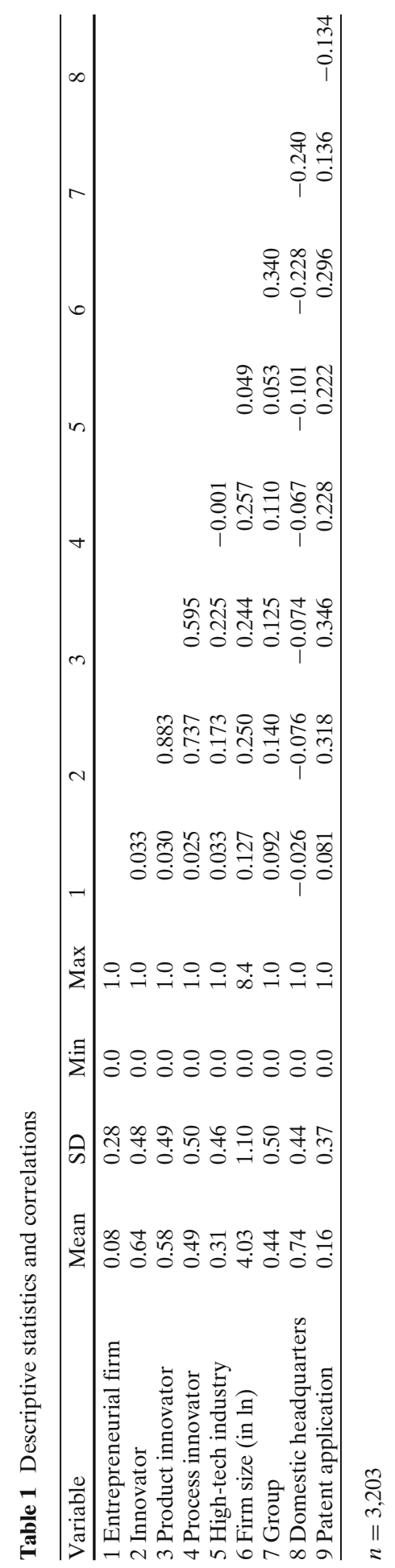


in different specifications of the model, to distinguish the effects on exit of the ability to innovate generally, from the effects of the specific nature of innovation. For the other main variables, correlation is relatively low and below a critical value for collinearity.

\section{The competing risks model}

In order to analyse the factors that influence the probability of firm exit while at the same time distinguishing the effects of these factors on the different forms such an event might assume (failure and M\&A), we estimate an independent competing risks model. This econometric model allows separation between the effects of the independent variables, according to exit by closure and exit by M\&A. We need to distinguish different types of exit from the market in the presence of several risks because the number of exits from any competing risk will influence the number of firms at risk of exit by the cause being analysed and, thus, the estimate of the probability of exiting by that mode (Gooley et al. 1999). Based on the discrete nature of our monthly exit data (exit events take place in continuous time, but are reported in discrete time), in particular, we apply the discrete-time method for competing risks model proposed by Allison (1982) and extended by Jenkins (1995, 2005).

In our competing risks model, for each firm we include a variable indicating the mode of exit, $J$, with the values $j=1, \ldots, k$ (in our case $j=1,2$ where 1 $=$ closure and $2=M \& A$ ) in addition to the random duration variable, $T$. Our model considers only one period whose duration ends when a firm exits the market due to one of $\mathrm{k}$ possible, mutually exclusive states. Let us consider the existence of $k$ random variables, $T_{(1)}, \ldots, T_{(k)}$, one for each exit, interpreted as latent duration. These are imaginary time periods used to construct the models where $T_{(j)}$ is the time to exit to state $j$, eliminating all other possible states. At each moment, entry into a certain state is dictated by the shortest latent time period, i.e. $T=\min \left\{T_{j}\right\}_{j}$. For each firm, only one $T_{(j)}$ is observed, with the others considered censored. The observed failure time $T=\min \left\{T_{j}\right\}_{j}$ is censored for firms that survive the period. Assuming that the random variables $T_{(1)}, \ldots, T_{(k)}$ are independent, the model is effectively one of independent competing risks. The discrete-time hazard rate specific to the exit mode $j$ for firm $i$ is defined as:

$$
h_{j i}(t)=\operatorname{Pr}\left\{T_{j i}=t \mid T_{j i} \geq t ; X_{i t}\right\}
$$

where $X_{i t}$ is the vector of the covariates. The specific hazard functions can be interpreted empirically as the fraction of survivors at time $t$ that subsequently exit by a certain mode of exit.

The probability of observing a time spell $t$ for a specific type of exit $j$ can then be expressed, applying properties of conditional probabilities, as follows:

$$
P_{j i}(t)=\operatorname{Pr}\left\{T_{j i}=t\right\}=h_{j i}(t) S_{i}(t-1)
$$


where $S(t)$ is the discrete time survivor function, which defines the probability of the observation being censored at time $t$. In turn, the survivor function can be rewritten as

$$
S_{i}(t)=\operatorname{Pr}\left\{T_{i}>t\right\}=\prod_{s=1}^{t}\left[1-h_{i}(s)\right]=\left[1-h_{i}(t)\right] S_{i}(t-1)
$$

where $h_{i}(t)$ is the hazard function for any type of exit. Substituting (3) into (2) leads to:

$$
P_{j i}(t)=\operatorname{Pr}\left\{T_{j i}=t\right\}=\frac{h_{j i}(t)}{1-h_{i}(t)} S_{i}(t)
$$

Under the assumption of independent competing risks, the hazard function for any type of exit is equal to the sum of the single hazard functions, specific to the various types of exit:.

$$
h_{i}(t)=h_{\text {closure }, i}(t)+h_{M \& A, i}(t)
$$

Therefore, to estimate the model it is necessary to specify only the form of the single hazard function specific to a type of exit, in relation to the covariates $X_{i t}$. Following Allison (1982) and Jenkins (1995) we assume a logistic-type function for the hazard rate and make a transformation that allows the log-likelihood to be rewritten as in a multinomial logit model, in which all time spells observed, for all firms, are considered as separate, independent observations (Allison 1982). ${ }^{5}$

\section{The empirical specification}

To emphasize whether being an entrepreneurial firm and an innovator, and the technology environment affects mode of exit we interacted the dummy variables for the different classes, namely, young firms (taken as a proxy for being an entrepreneurial firm) and belonging to a high or low tech-sector, with various innovation dummies, in particular, being an innovator or not, having introduced a product innovation or not, and having introduced a process innovation or not. We introduced the interaction variables at two or at three terms in the models, in order to disentangle the effects of different groups of firms. We apply the interaction models proposed in Wright (1976) and Brambor et al. (2006) for the specific case that the modifying variable is discrete. This specification of the interaction models is based on the generalized linear model approach proposed in Wright (1976) to assess the extent of

\footnotetext{
${ }^{5} \mathrm{We}$ also conducted a sensitivity analysis by estimating a complementary log-log model, which is the discrete time equivalent of a continuous-time proportional hazards model (Prentice and Gloeckler 1978). The results of the sensitivity analysis, which are available on request, are in line with those obtained from estimation of the competing risks model, in discrete time, using the multinomial logit formulation.
} 
change in conditional relationships among subsets of observations defined by a conditioning variable.

We use this model to analyze the extent to which the impact of firm age on different modes of exit is different for different groups of firms, accounting for their different technological classes (high-tech and low-tech), and innovative capabilities. Models 1 and 2 are estimated as follows:

$$
\begin{aligned}
\operatorname{Pr}(\text { exit_mode }=j)= & \text { Multi } \Lambda\left(W_{i}^{\prime} \alpha+\beta \text { pat-appl }+\gamma_{1} \text { entrepr } *\right. \text { innov } \\
& +\gamma_{2} \text { entrepr } * \text { non-innov }+\delta_{1} \text { high-tech } * \text { innov } \\
& +\delta_{2} \text { high-tech } * \text { non-innov }+\varphi_{1} \text { low-tech } * \text { innov } \\
& \left.+\varphi_{2} \text { low-tech } * \text { non-innov }\right)
\end{aligned}
$$

where:

- Multi $\Lambda$ indicates the multinomial logit formulation

- exit_mode is the dependent variable which can take the values: 0 if firms survive; 1 if firms exit the market due to closure; 2 if firms exit the market due to M\&As. Our comparison group is composed of firms that survive.

- $\quad W_{i}$ is the set of the control variables for the firm's mode of exit. It includes the logarithm of number of employees as a proxy of firm size (ln size); the square of the logarithm, to capture the non linear effects of firm size on mode of exit (size 2); a dummy for whether the firm belongs to a group (group); and a dummy that denotes whether the headquarters of the group is located in the Netherlands (domestic headquarters).

- $\quad$ ppat-appl controls for the effect of patenting activity, and pat-appl is a dummy variable indicating whether the firm applied for at least one patent in the period 1994-1996.

- $\quad \gamma_{1}$ entrepr $*$ innov $+\gamma_{2}$ entrepr $*$ non-innov (which is included in Models 1 and 2) captures the effects of being an entrepreneurial firm (conditional on whether or not the firm innovates) on exit probabilities. The dummy entrepr identifies firms that are 5 years or younger, innov is equal to 1 if the firm innovates and zero otherwise; non-innov is equal to 1 if the firm does not innovate.

In Model 2, $\delta_{1}$ high-tech $*$ innov $+\delta_{2}$ high-tech $*$ non-innov identifies the effects on the exit probabilities of being an innovator in a high-tech sector (identified by the dummy high-tech) and of being a non-innovator in a hightech sector.

In Model 2, $\varphi_{1}$ low-tech $*$ innov $+\varphi_{2}$ low-tech $*$ non-innov expresses the effects of being an innovator in a low-tech sector (identified by the dummy variable low-tech), and of being a non-innovator in a low-tech sector. In the estimation of the coefficients, the effect of low-tech*non-innov is dropped because of multi-collinearity.

In Model 3 we check for interaction among three dummy variables: in this formulation the effects of being a (young) entrepreneurial firm on the exit probabilities are conditional on both innovativeness (whether the firm is an 
innovator or not) and the technological intensity of the industry (belonging to a high-tech or a low-tech sector).

$$
\begin{aligned}
\operatorname{Pr}(\text { exit_ } \bmod e=j)= & \text { Multi } \Lambda\left(W_{i}^{\prime} \alpha+\beta \text { pat-appl }+\gamma_{1} \text { entrepr } *\right. \text { high-tech } \\
& * \text { innov }+\gamma_{2} \text { entrepr } * \text { high-tech } * \text { non-innov } \\
& +\gamma_{3} \text { entrepr } * \text { low-tech } * \text { innov }+\gamma_{4} \text { entrepr } \\
& * \text { low-tech } * \text { non-innov }
\end{aligned}
$$

Similar formulations are estimated in Models 4 and 5, which distinguish between product and process innovation. These models include dummy variables for product innovation (product innov), process innovation (process innov), non-product innovating firms (non product-innov) and non-process innovators (non process-innov). The formulation of Eq. 7, which includes the interaction among three dummy variables, is extended to account for the different types of innovation in Model 6.

In all the model formulations, the independent variables are defined as the initial conditions observed at a certain time period (1994-1996), after which we track the firm's event history over a number of years. While some conditions, such as sector of activity, are fairly invariant over time, the firm's innovative capabilities can change. After the initial observation, some firms may continue to innovate, while others may innovate only sporadically or not at all (Cefis 2003). One of the limitations of the present analysis is that it does not account for how changes in innovative capabilities influence exit behaviour. On the other hand, our approach has the advantage that endogeneity is mitigated, given the time lag between observation of the independent variables as the initial conditions and the occurrence of an exit event. The problem of endogeneity is more likely to emerge with the use of time-dependent covariates, because firm innovation will be observed repeatedly over time, and eventually closer to a possible exit event.

\section{Empirical results}

Table 2 compares the proportions of innovators and non-innovators by age class, type of innovation, and technology environment. In the total sample, the number of innovators among young firms is more than twice the number of non-innovators; among older firms, the number of innovators is about $70 \%$ higher than non-innovators. If we look at type of innovation and technology environment, we can see that young firms are more innovative (in the sense that a larger share of young firms innovates) than older firms, in almost all categories, with the exception of product innovation in high-tech industries, where older firms are just slightly more innovative than young firms.

Table 3 presents the estimates of the competing risks model, which includes two-way interactions between age, innovation, and technology environment. 
Table 2 Proportion of innovators on non-innovators by age, type of innovation and industry's technology intensity

\begin{tabular}{lll}
\hline & Firm age & \\
\cline { 2 - 3 } & $\leq 5$ years & $>5$ year \\
\hline Total & 2.22 & 1.71 \\
High tech industry & 3.32 & 3.18 \\
Low tech industry & 1.82 & 1.35 \\
Product innovation & 1.67 & 1.34 \\
Process innovation & 1.12 & 0.93 \\
Product innov * high tech & 2.80 & 2.92 \\
Product innov * low tech & 1.29 & 0.99 \\
Process innov * high tech & 1.11 & 0.93 \\
Process innov * low tech & 1.12 & 0.94 \\
\hline
\end{tabular}

Table 3 Estimates of multinomial logistic regression with two-way interaction effects

\begin{tabular}{|c|c|c|c|c|c|c|}
\hline & \multicolumn{3}{|l|}{ Model 1} & \multicolumn{3}{|l|}{ Model 2} \\
\hline & $\overline{R_{R R}}{ }^{a}$ & $\begin{array}{l}\text { Robust } \\
\text { Std. err. }\end{array}$ & $\overline{\mathrm{P}>|z|}$ & $\mathrm{RRR}^{\mathrm{a}}$ & $\begin{array}{l}\text { Robust } \\
\text { Std. err. }\end{array}$ & $\mathrm{P}>|z|$ \\
\hline \multicolumn{7}{|l|}{ Exit by closure } \\
\hline ln size & 0.43 & 0.079 & 0.000 & 0.43 & 0.078 & 0.000 \\
\hline $\mathrm{Size}^{\wedge}$ & 1.06 & 0.024 & 0.006 & 1.07 & 0.023 & 0.003 \\
\hline Group & 1.43 & 0.160 & 0.001 & 1.46 & 0.163 & 0.001 \\
\hline Domestic headquarters & 0.92 & 0.112 & 0.476 & 0.92 & 0.113 & 0.499 \\
\hline Patent application & 0.83 & 0.141 & 0.266 & 0.91 & 0.163 & 0.603 \\
\hline Entrepr $*$ innovator & 1.53 & 0.323 & 0.043 & 1.79 & 0.386 & 0.007 \\
\hline Entrepr * non-innovator & 2.81 & 0.633 & 0.000 & 2.24 & 0.521 & 0.001 \\
\hline High-tech $*$ innovator & & & & 0.82 & 0.173 & 0.352 \\
\hline Low-tech * non-innovator & & & & 1.09 & 0.204 & 0.644 \\
\hline Low-tech $*$ innovator & & & & 0.61 & 0.124 & 0.015 \\
\hline Logt & 1.83 & 0.132 & 0.000 & 1.84 & 0.132 & 0.000 \\
\hline \multicolumn{7}{|l|}{ Exit by M\&A } \\
\hline ln size & 0.53 & 0.135 & 0.012 & 0.51 & 0.129 & 0.008 \\
\hline $\operatorname{Size}^{\wedge}$ & 1.06 & 0.030 & 0.028 & 1.07 & 0.030 & 0.026 \\
\hline Group & 2.03 & 0.278 & 0.000 & 2.02 & 0.275 & 0.000 \\
\hline Domestic headquarters & 1.41 & 0.230 & 0.037 & $\mathbf{1 . 3 5}$ & 0.220 & 0.062 \\
\hline Patent application & 0.69 & 0.129 & 0.045 & 0.75 & 0.144 & 0.137 \\
\hline Entrepr $*$ innovator & 1.69 & 0.372 & 0.018 & 1.60 & 0.359 & 0.038 \\
\hline Entrepr $*$ non-innovator & 1.08 & 0.429 & 0.848 & 1.25 & 0.510 & 0.589 \\
\hline High-tech $*$ innovator & & & & 1.03 & 0.339 & 0.938 \\
\hline Low-tech * non-innovator & & & & 1.49 & 0.452 & 0.191 \\
\hline Low-tech * innovator & & & & 1.94 & 0.583 & 0.027 \\
\hline Logt & 1.77 & 0.115 & 0.000 & 1.77 & 0.116 & 0.000 \\
\hline Number of obs & 245,333 & & & 245,333 & & \\
\hline Wald chi2 & 299.72 & & & 333.27 & & \\
\hline Prob $>$ chi 2 & 0.00 & & & 0.00 & & \\
\hline Log pseudolikelihood & $-4,930.11$ & & & $-4,911.28$ & & \\
\hline
\end{tabular}

Coefficients statistically significant at $10 \%$ are highlighted in bold

${ }^{a}$ RRR (relative risk ratios) are equivalent to odds ratios in a binary logistic regression. A value above one indicates a positive effect of the independent variable on the probability of the corresponding event to occur, while a value below one indicates a negative effect 
The variable for innovation is the general one that accounts for whether the firm has innovated or not, independent of the type of innovation. The model is estimated in two stages. First, we consider a baseline model with only the interaction between firm age and innovation, and the control variables (Model 1). We then add the interaction effects between innovation and the technology environment (Model 2). All model estimates are reported as relative risk ratios (RRR), which, in a multinomial logistic regression, are equivalent to odds ratios in a binary logistic regression. For a given mode of exit, an odds ratio value greater than 1 indicates that the effect of the corresponding variable on the probability to exit is positive; a value smaller than 1 indicates that the effect has a negative sign.

Starting with Model 1 for exit by closing down activities, we observe that the odds ratios for young and innovative firms and young and non-innovative firms are significantly greater than 1 (1.53 and 2.81 respectively): young firms have a higher probability of failure than old firms, independent of whether or not they are innovative. This confirms that there is a liability of newness, in general. Also, the odds ratio for young and non-innovative firms is substantially higher than the odds ratio for young and innovative firms. Young firms that do not innovate are more likely to close down activities with a three times higher probability than other firms, and the probability is $50 \%$ higher for young firms that are innovators. The effect of ageing on the exit probability is more pronounced for non-innovators than for innovators, implying that innovation negatively moderates the effect of firm age on the probability to exit by closure. Thus, for young firms, innovating effectively reduces the liability of newness. A similar pattern is observed if we include in Model 2, the interaction between innovation and the technology environment. In the extended model, the odds ratios of young firms that innovate and of young firms that do not innovate are statistically significant, and equal to 1.79 and 2.24 , respectively.

If we look at the interaction effect of innovation and the technology environment on the probability of closing down activities, we find that among the various combinations, the effect is statistically significant only in the case of innovators in low-tech industries. In Model 2, an odds ratio value of less than 1 (0.61) indicates that firms in low-tech industries that innovate have the lowest probability of exiting by closure, at about $40 \%$ lower than other firms on average. Somewhat unexpectedly, we find that innovation in hightech industries does not have a statistically significant effect on the probability to exit by closure. These results suggest that being an innovator has a bigger effect on survival in low-tech compared to high-tech environments. In hightech industries, innovation is a necessary, but not sufficient condition for survival. In fast-changing environments firms need to innovate, but this does not guarantee their survival. To be able to achieve a competitive advantage that is likely to increase the likelihood of survival compared to other firms in the industry, innovators need to distinguish behavior on other dimensions, for example in the novelty of the innovation. Conversely, in low-tech industries, innovation is a sufficient condition for survival. In a stable environment, being an innovator is enough to differentiate the firm from the rest of the industry, 
and to capture competitive advantage, which endows the firm with a higher prospect of survival compared to other firms.

In terms of exit by M\&A, the lower section of Table 3 shows that for Model 1, the odds ratio is statistically significant and greater than 1 (1.69) for young and innovative firms, but for young and non-innovative firms it is not statistically significant. This effect remains much the same (estimated odds ratio is 1.60) if we add to the model the interaction between innovation and the technology environment (Model 2). These results show that young innovative firms are preferred for acquisitions; their probability of being acquired is about $60 \%$ higher on average than for other firms. This is based on their potential for growth, while their organization and financial structures are still weak. Model 2 shows also that exit through acquisition is most likely for firms that innovate in a low-tech industry. As already noted, being innovative provides stronger differentiation and higher rewards for survival in low-tech than in high-tech industries. In high tech industries, innovation is more diffuse; thus, firms wanting to differentiate themselves need to be highly innovative. Accordingly, innovative firms in low-tech industries are not only more likely than others to survive, but, because of their distinctive quality, they are more attractive as acquisitions.

To identify the combined effect of firm innovation and technology environment on the exit behaviour of entrepreneurial firms, Model 3 includes threeway interaction of firm age, firm innovation and technology intensity in the industry. The results in Table 4 show that the group most exposed to the risk of failure, or exit by closure, is composed of young, low tech industry firms, that do not innovate (odds ratio $=3.49$ ) where the liability of newness is the most critical. The odds ratio is also statistically significant and greater than 1 for the opposite category of young firms, that is, young firms that innovate in high-tech industries also experience high probabilities of exit by closure (odds ratio $=2.48$ ). Based on our earlier observations, a possible explanation for this is that since in high-tech industries innovation is not a sufficient condition for survival, as innovation is the common denominator, young firms need to be highly innovative to achieve differentiation from competitors. This involves higher risks and, therefore, a higher probability of exit due to failure. In relation to entrepreneurial firms' survival, lack of innovative capabilities in low-tech industries and the uncertainty associated with highly innovative projects in high-tech industries seems to increase the probability of exit by closure. The liability of newness is thus reinforced by changing too little in a stable environment or by changing too much in a dynamic environment.

For the estimates on exit by M\&A, in the three-way interaction model, the only case where we observe a statistically significant effect among the various combinations, is young firms innovating in low-tech industries (odds ratio 1.84). This result confirms our earlier observation that innovators in lowtech industries are more 'exceptional' than innovators in high-tech industries and the benefit derived from innovation is proportionally higher. Because of this, innovative firms in low-tech industries have a lower risk of exiting due 
Table 4 Estimates of multinomial logistic regression with three-way interaction effects

\begin{tabular}{llll}
\hline & Model 3 & & \\
\cline { 2 - 4 } & RRR & Robust Std. err. & $\mathrm{P}>|z|$ \\
\hline Exit by closure & & & \\
ln size & $\mathbf{0 . 4 4}$ & 0.079 & 0.000 \\
Size` & $\mathbf{1 . 0 6}$ & 0.024 & 0.007 \\
Group & $\mathbf{1 . 4 3}$ & 0.161 & 0.001 \\
Domestic headquarters & 0.91 & 0.112 & 0.465 \\
Patent application & 0.79 & 0.138 & 0.186 \\
Entrepr * high-tech * non-innov. & 1.17 & 0.706 & 0.791 \\
Entrepr * high-tech * innov. & $\mathbf{2 . 4 8}$ & 0.682 & 0.001 \\
Entrepr * low-tech * non-innov. & $\mathbf{3 . 4 9}$ & 0.839 & 0.000 \\
Entrepr * low-tech * innov. & 1.02 & 0.316 & 0.960 \\
Logt & 1.84 & 0.133 & 0.000 \\
Exit by M\&A & & & \\
ln size & $\mathbf{0 . 5 2}$ & 0.134 & 0.011 \\
Size`2 & $\mathbf{1 . 0 6}$ & 0.030 & 0.027 \\
Group & $\mathbf{2 . 0 2}$ & 0.277 & 0.000 \\
Domestic headquarters & $\mathbf{1 . 4 1}$ & 0.229 & 0.037 \\
Patent application & $\mathbf{0 . 7 0}$ & 0.130 & 0.052 \\
Entrepr * high-tech * non-innov. & 0.52 & 0.530 & 0.519 \\
Entrepr * high-tech * innov. & 1.38 & 0.550 & 0.413 \\
Entrepr * low-tech * non-innov. & 1.32 & 0.567 & 0.514 \\
Entrepr * low-tech * innov. & $\mathbf{1 . 8 4}$ & 0.475 & 0.017 \\
Logt & 1.77 & 0.115 & 0.000 \\
Number of obs & 245,333 & & \\
Wald chi2 (20) & 320.96 & & \\
Prob > chi2 & 0.00 & & \\
Log pseudolikelihood & $-4,924.90$ & & \\
\hline
\end{tabular}

See Table 3

to failure, but attract more attention from potential acquirers. The results in Table 4 show that this is especially true for young firms. Young firms innovating in low-tech sectors are more likely to be acquired by an established firm, which 'buys' the potential for growth of the young innovative firm that is financially and structurally weak, in a stable environment where technological opportunities are scarce, and much sought after.

If we distinguish between innovations in products and in processes, we observe that the nature of innovation contributes to explaining the exit behaviour of new firms, and the way exit behaviour responds to the environmental conditions in which firms operate. Table 5 shows that the probability to exit by closure is highest for young firms that are not product innovators; the odds ratio in Model 4 is 2.09 , indicating that this category of firms is exposed to double the risk of exit on average, than other firms. Competition through the introduction of new products, in the context of our analysis, is the most important factor discriminating between survival and death of new firms. The effect persists if we add to the model the interaction between firm innovation and the technology environment (Model 5). We see that innovation 
Table 5 Estimates of multinomial logistic regression with two-way interaction effects and type of innovation

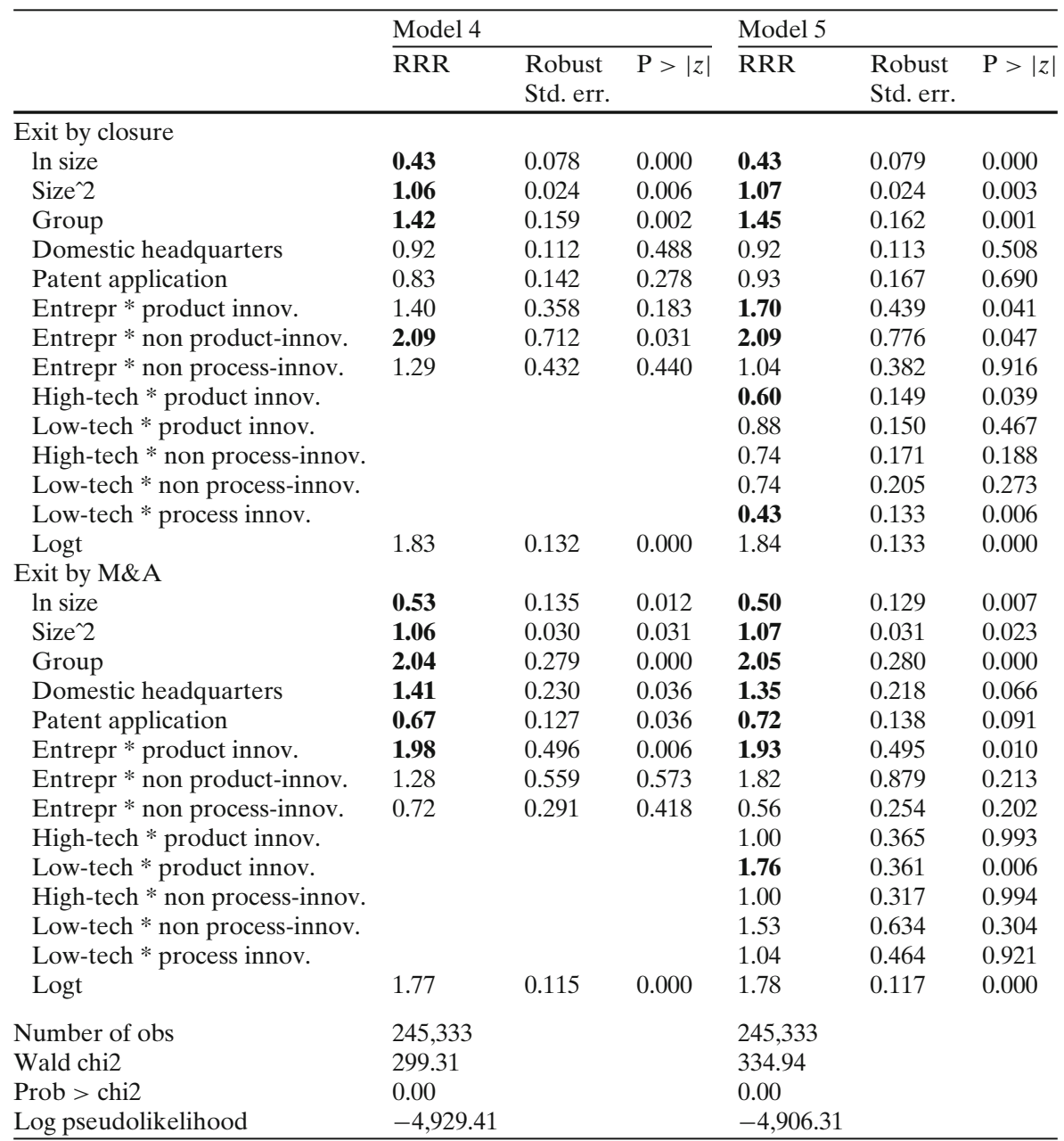

See Table 3

has a positive effect on the liability of newness, only if the firm is a product innovator. In this model specification, the odds ratio is statistically significant and greater than 1 for new firms - both product and non-product innovators, indicating that there is a liability of newness generally. However, the effect is stronger for young firms that are not product innovators, which have a probability of failure twice that of other firms on average (odds ratio $=2.09$ ). For product innovating new firms, the exit probability is $70 \%$ higher than for other firms (odds ratio $=1.70$ ). The coefficients for process innovation are not statistically significant in either Model 4 or Model 5. 
The above results indicate that there is a liability of newness, which is mitigated by the ability of new firms to innovate in products, but that process innovation activity does not have a similar impact. Model 5 shows that, independent of firm age, process innovation significantly lowers the probability of exit by failure in low-tech industries (odds ratio $=0.43$ ), while product innovation has a similar effect in high-tech industries (odds ratio $=0.60$ ). This suggests that in stable environments, what is especially important for firm survival is that companies adapt by changing their production processes and lowering costs, while in rapidly changing environments, adaptation, and survival, requires the introduction of new products.

The nature of innovation influences the probability to exit by M\&A. The lower part of Table 5 shows that the group of firms most likely to exit by M\&A are young firms that are product innovators. This is the only group among the various combinations of type of innovation and age, for which we observe a statistically significant effect. The odds ratio is 1.98 in Model 4 and 1.93 in Model 5. This means that young firms that are product innovators are roughly twice as likely on average to exit by M\&A than other firms. Entrepreneurial firms with new product offerings are attractive and visible targets for acquisitions by older and larger, firms. In Model 5, which accounts for industry technological class, we find (somewhat surprisingly) that the introduction of new products increases the probability of being acquired for firms in low-tech (odds ratio $=1.76$ ), but not high-tech industries (coefficient not statistically significant). In low-tech industries, product innovation is less common and, as already shown, firm survival is positively affected by process innovation. In a stable environment, where firms adapt by innovating in processes, product innovation becomes 'exceptional', competition is less intense, and acquisition by a competitor is more likely.

The estimates in Table 6 combine the two mechanisms described above, of the moderating effect of innovation on the liability of newness, and the fit between firm innovation and technology environment, into a single model that accounts for this three-way interaction (Model 6). For exit by closure, it seems that the liability of newness is heaviest for firms in low-tech industries that are not process innovators (odds ratio $=2.31$ ). As already mentioned, it is process innovation that ultimately sustains the survival of firms in stable environments; in these conditions, it is new firms that cannot adapt their internal processes and control production costs, that are the most likely to fail. For exit by M\&A, the probability of being acquired is highest for young firms in low-tech industries that are product innovators (odds ratio $=2.23$ ). In stable environments, product innovators based on their exceptionality, make attractive targets for acquirers. The estimates in Model 6 indicate that this is especially true of new firms that are the sources of innovation. This path to exit via acquisition, may reflect the fact that new firms lack the resources required to compete in the market with new products, or may indicate adoption of an exit strategy where a new firm is created with the objective of selling on. 
Table 6 Estimates of multinomial logistic regression with three-way interaction effects and type of innovation

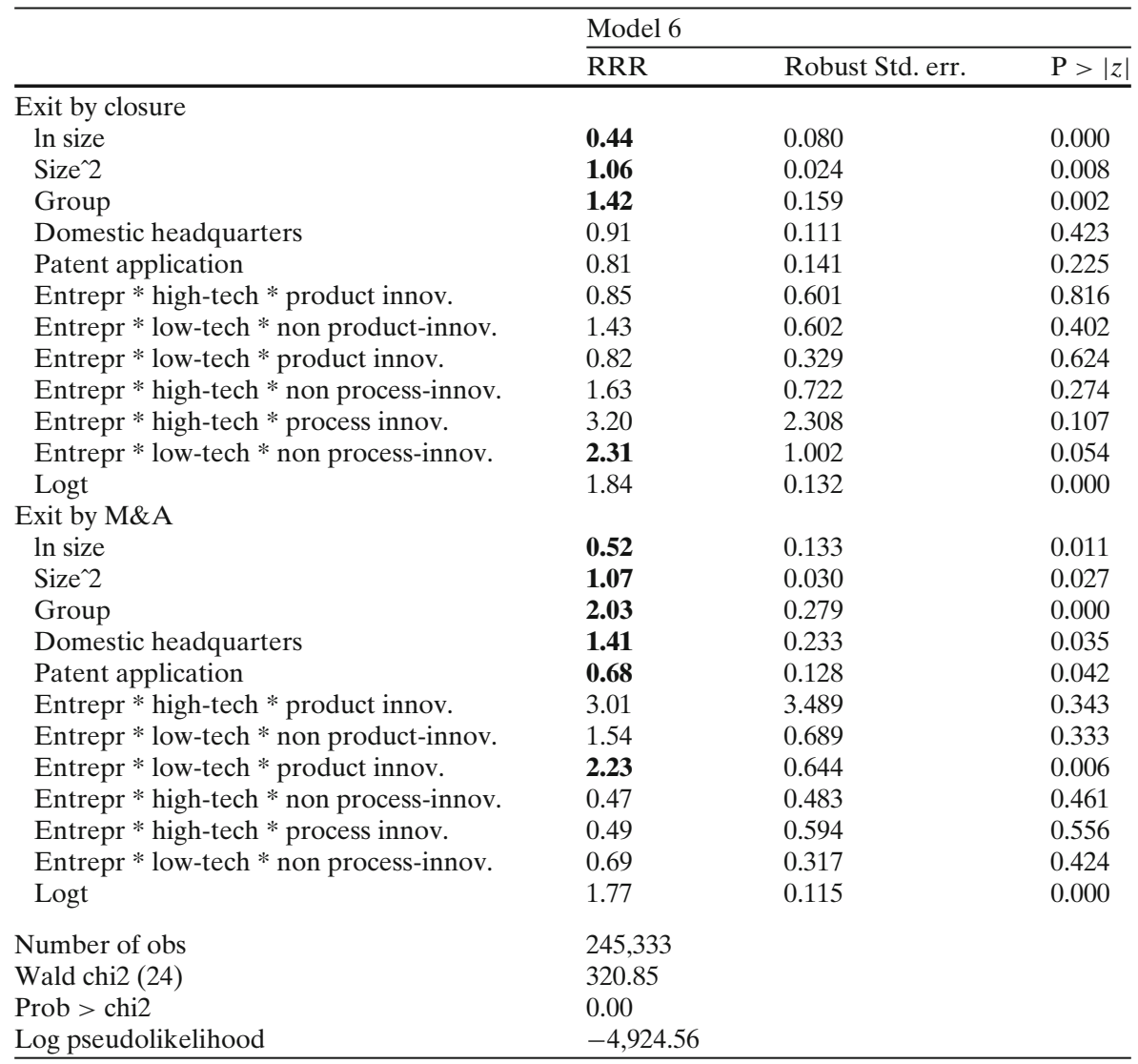

See Table 3

\section{Control variables}

In all the specifications, firm size has a negative and statistically significant effect (odds ratio below 1) on the probability of exiting through closing down activities or by M\&A. This confirms the well-known fact that larger firms are more likely to survive, indicating that this outcome, in almost equal measure, is due to larger firms being less likely to close down activities or to be acquired. If we use the squared term of firm size, the variable has a positive and statistically significant effect (odds ratio greater than 1) in all the model specifications, for exit by both closure and M\&A. Combined with the previous result, this implies that firm size reduces the probability of exiting - through either mode-at a decreasing rate: while size contributes to survival, above a certain threshold some firms may become too big to survive. 
With regard to firm ownership structure, we observe that, independent of the model specification and form of exit, ownership structure has a statistically significant effect on exit probabilities (odds ratio above 1). More specifically, firms that are part of a group have a more than $40 \%$ higher probability of closing down than firms that are independent units. For exit by M\&A, the effect is stronger: firms that are part of a group are twice as likely to be acquired than independent firms. These results confirm that it is easier for a multi-unit firm to close down a subsidiary or to sell it on, than it is for a wholly independent firm. The opportunity costs of closing down or selling a firm are lower for managers responsible for deciding about the future of a subsidiary firm than for the entrepreneurs where the decision is whether or not to stay in the market with their own company. Our findings suggest that entrepreneurs tend to wait longer than managers before deciding on exit, either by closure of activities or selling the firm or subsidiary. Although acquisition may represent successful exit, founders are more reluctant to sell their companies than are managers of multi-unit firms to sell a subsidiary.

In controlling for differences between Dutch companies and foreign subsidiaries, differences in exit behaviour are statistically significant only in the case of exit by M\&A. In particular, firms with headquarters in the Netherlands have an approximately $40 \%$ greater probability of being acquired than subsidiaries of multinational firms. It may be that while a multi-national can easily exit a national market by closing down a subsidiary, in this case, facing similar conditions to national firms, it may be more difficult to exit by selling on to or merging with another firm. Because of institutional distance between the foreign subsidiary and the host country, negotiating and implementing an M\&A may be more difficult based on the different rules, norms and values of the parties involved.

Finally we control for the firm's patenting activity. The estimated coefficients of this variable are statistically significant only for exit by M\&A, and not significant for exit by closure. Values of the odds ratio below 1 indicate that the probability of being acquired is lower for patenting firms than firms that have not patented (odds ratio in the range $0.67-0.72$ ). Patenting lowers the probability of being acquired of about $30 \%$. The fact that patenting does not have a statistically significant effect on the probability of exit by closing the firm suggests that ultimately what matters for survival is whether or not the firm is an innovator. Innovative capabilities allow firms to adapt to changes in the environment and to competition, and thus to survive. Award of a patent does not endow additional advantage in terms of the likelihood of survival. However, patent ownership lowers the probability of being acquired. Patenting may be an indication of the choice of the firm to exploit its innovation in the product market and to protect it from imitation, rather than a desire to sell its idea-and the company-to potential competitors. Also, patents can be an effective way of signaling value to external funders and winning more financial resources. Thus, firms that patent are better equipped to face competition in product markets, rather than selling on. Our control variable distinguishes only whether a firm has patented or not; it does not account for the value of the 
patent portfolio. As Wagner and Cockburn (2010) observe, while patenting in general lowers the probability of being acquired, it is only exceptionally valuable patents that will attract the attention of potential buyers of the firm and increase the probability to exit by acquisition.

\section{Conclusions}

Starting from a central problem in organizational ecology research that new firms experience a liability of newness because of lack of resources (physical, knowledge and social), we explored the conditions that may reduce or reinforce this liability. We focus on two conditions: the existence and type of innovative capabilities at firm level, and the fit between these capabilities and the technology environment in which firms are positioned. We find, that although there is a general liability of newness, innovation activity allows new firms to compensate for or reduce this liability quite significantly. The effectiveness of this strategy for entrepreneurs depends on the type of innovation: product innovation plays a greater role than process innovation in moderating the liability of newness, with respect to both types of exit considered-closure of the firm and M\&A. The role of product innovation is twofold. While it lowers the probability that a new firm will exit by closing down activities (liability of newness is lower), it increases the probability that a new firm will exit as a result of an M\&A (liability of newness is higher).

Also, the relationship between age, exit and innovation is conditional on the nature of the technology environment. Entrepreneurs seem to face two different dynamics of competition, driven by innovation in low-tech and hightech industries. We find that in high tech-industries, where the ability of firms to adapt and survive depends on the introduction of new products, new firms that innovate in products are in the same position in terms of firm survival as other (older) firms, on average. In fast changing environments, firms need to innovate just to maintain their positions, and competition can assume the form of 'Red Queen' evolution (Barnett and Hansen 1996). Innovation is driven by a process of adaptive learning: as a firm innovates in the attempt to improve its competitive position, other firms will follow and also try to innovate as they see their competitive positions in the market threatened by the action of the early innovator. As firms adapt in light of others' innovations, the relative position or fit of individual firms will remain unchanged, but the average level of competitiveness in the industry will increase. Competition thus becomes a race in which everyone must keep running in order to maintain their positions with respect to others (Barnett and Hansen 1996). If we consider the nature of innovation, products innovations generally increase the environmental fit of innovators in high-tech sectors. However, this does not provide a distinctive advantage for entrepreneurial firms, in terms of an enhanced likelihood of survival. In a fast changing environment, product innovation is a necessary condition to remain in the innovation race, but is not sufficient to increase the chances of success, of either established or new firms. 
In low-tech industries, firm survival depends especially on the ability of firms to change and improve their production processes. In these conditions, where competition takes place through cost saving measures, young firms that are not able to adapt their production processes and to keep their costs low, are very exposed to the liability of newness, and are most likely to fail. In this context, where process innovation is crucial for survival, product innovation assumes a distinctive role and creates the opportunities for successful exit. In stable environments, where competition in production efficiency is strong but weaker in relation to products, the introduction of a new product is a source of 'exceptional' variation. Young firms that are product innovators become particularly attractive targets for acquisition. In stable environments, where little change is generated internally, innovations by new firms are a source of change from the outside, a mutation which is passed on to established firms through the M\&A process.

Our findings indicate that for new firms in fast changing environments, developing the capabilities required for the introduction of new products or processes is not enough to succeed. It is possible that new firms may need to focus on radical innovation in order to differentiate themselves and establish competitive advantage. However, as some of our results suggest, this strategy may increase rather than reduce the risk of failure, as it means that firms face greater uncertainty. A limitation of our study is that we do not distinguish between incremental and radical innovation. We adopted a broad definition of innovation because of the complexity of the relationships we were trying to disentangle, which involve multiple dimensions of exit and innovation, not previously studied simultaneously. Future research could investigate whether the type of innovation-incremental or radical—has a different impact on the types of relationships found in this study.

Acknowledgements We thank participants in the Revolving Doors: Entrepreneurial Survival and Exit workshop at the Rotterdam School of Management, and two referees for valuable comments and suggestions. The empirical part of this research was carried out at the Centre for Policy Related Statistics at Statistics Netherlands (CBS). The views expressed in this paper are those of the authors and do not necessarily reflect the policies of Statistics Netherlands. Elena Cefis acknowledges the financial supports of the Utrecht University [High Potential Grant (HIPO)]; and the University of Bergamo [grant ex 60\%, n. 60CEFI10, Dept. of Economics].

Open Access This article is distributed under the terms of the Creative Commons Attribution Noncommercial License which permits any noncommercial use, distribution, and reproduction in any medium, provided the original author(s) and source are credited.

\section{References}

Agarwal R (1996) Technological activity and survival of firms. Econ Lett 52:101-108

Agarwal R (1998) Small firm survival and technological activity. Small Bus Econ 11:215-224

Allison PD (1982) Discrete-time methods for the analysis of event histories. Sociol Method 13: 61-98

Audretsch DB (1991) New-firm survival and the technological regime. Rev Econ Stat 73:441-450 
Audretsch DB, Mahmood T (1994) The rate of hazard confronting new firms and plants in US manufacturing. Rev Ind Organ 9:41-56

Audretsch DB, Mahmood T (1995) New firm survival: new results using a hazard function. Rev Econ Stat 77:97-103

Barnett WP, Hansen MT (1996) The red queen in organizational evolution. Strateg Manage J 17:139-157

Bloodgood JM, Sapienza HJ, Almeida JG (1996) The internationalization of new high-potential US ventures: antecedents and outcomes. Entrep Theory Pract 20:61-76

Bracker J, Pearson J (1986) The impact of franchising on the financial performance of small firms. J Acad Mark Sci 14:10-17

Brambor T, Clark WR, Golder M (2006) Understanding interaction models: improving empirical analyses. Polit Anal 14:63-82

Caves RE (1998) Industrial organization and new findings on the turnover and mobility of firms. J Econ Lit 36:1947-1982

Caves RE, Porter ME (1976) Barriers to exit. In: Masson RT, Qualls PD (eds) Essays on industrial organization in honor of Joe S. Bain. Ballinger, Cambridge

Cefis E (2003) Is there persistence in innovative activities? Int J Ind Organ 21:489-515

Cefis E, Marsili O (2005) A matter of life and death: innovation and firm survival. Ind Corp Change 14:1-26

Cefis E, Marsili O (2006) Innovation premium and the survival of entrepreneurial firms. In: Santarelli E (ed) Entrepreneurship, growth, and innovation: the dynamics of firms and industries. Springer, Heidelberg

Cefis E, Marsili O (2007) Going, going, gone. Innovation and exit in manufacturing firms. ERIM Report Series. Reference No. ERS-2007-015-ORG

Coff RW (1999) How buyers cope with uncertainty when acquiring firms in knowledge-intensive industries: caveat emptor. Organ Sci 10:144-161

Cohen WM, Levinthal DA (1990) Absorptive capacity: a new perspective on learning and innovation. Adm Sci Q 35:128-152

Dosi G, Marsili O, Orsenigo L, Salvatore R (1995) Learning, market selection and the evolution of industrial structures. Small Bus Econ 7:411-436

Evans DS (1987) The relationship between firm growth, size, and age: estimates for 100 manufacturing industries. J Ind Econ 35:567-581

Freeman J, Carroll GR, Hannan MT (1983) The liability of newness: age dependence in organizational death rates. Am Sociol Rev 48:692-710

Gans JS, Stern S (2003) The product market and the market for "Ideas": commercialization strategies for technology entrepreneurs. Res Policy 32:333-350

Geroski PA (1995) What do we know about entry? Int J Ind Organ 13:421-440

Geroski PA, Mata J, Portugal P (2010) Founding conditions and the survival of new firms. Strateg Manage J 31(5):510-529

Gimeno J, Folta TB, Cooper AC, Woo CY (1997) Survival of the fittest? Entrepreneurial human capital and the persistence of underperforming firms. Adm Sci Q 42:750-783

Gooley TA, Leisenring W, Crowley J, Storer BE (1999) Estimation of failure probabilities in the presence of competing risks: new representations of old estimators. Stat Med 18:695-706

Gort M, Klepper S (1982) Time paths in the diffusion of product innovations. Econ J 92:630-653

Headd B (2003) Redefining business success: distinguishing between closure and failure. Small Bus Econ 21:51-61

Jenkins SP (1995) Easy estimation methods for discrete-time duration models. Oxf Bull Econ Stat 57:129-138

Jenkins SP (2005) Survival analysis. Institute for Social and Economic Research, University of Essex, Colchester, UK. Downloadable from http://www.iser.essex.ac.uk/teaching/degree/ stephenj/ec968/pdfs/ec968lnotesv6.pdf

Mahmood T (1992) Does the hazard rate for new plants vary between low- and high-tech industries? Small Bus Econ 4:201-209

McDougall PP, Oviatt BM, Shrader RC (2003) A comparison of international and domestic new ventures. J Int Entrepreneur 1:59-82

Nelson RR, Winter SG (1982) An evolutionary theory of economic change. Belknap Press of Harvard University Press, Cambridge

OECD (2001) Science, technology and industry scoreboard. OECD, Paris 
Prentice RL, Gloeckler LA (1978) Regression analysis of grouped survival data with application to breast cancer data. Biometrics 34:57-67

Ranft AL, Lord MD (2002) Acquiring new technologies and capabilities: a grounded model of acquisition implementation. Organ Sci 13:420-441

Sarkar M, Echambadi R, Agarwal R, Sen B (2006) The effect of the innovative environment on exit of entrepreneurial firms. Strateg Manage J 27:519-539

Silverberg G, Dosi G, Orsenigo L (1988) Innovation, diversity and diffusion: a self-organisation model. Econ J 98:1032-1054

Sorensen JB, Stuart TE (2000) Aging, obsolescence, and organizational innovation. Adm Sci Q 45:81-112

Stearns TM, Carter NM, Reynolds PD, Williams ML (1995) New firm survival: industry, strategy, and location. J Bus Venturing 10:23-42

Teece DJ (1986) Profiting from technological innovation: implications for integration, collaboration, licensing and public policy. Res Policy 15:285-305

Wagner S, Cockburn I (2010) Patents and the survival of internet-related ipos. Res Policy 39: 214-228

Wennberg K, Wiklund J, DeTienne DR, Cardon MS (2010) Reconceptualizing entrepreneurial exit: divergent exit routes and their drivers. J Bus Venturing 25(4):361-375

Winter SG (1984) Schumpeterian competition in alternative technological regimes. J Econ Behav Organ 5:287-320

Wright G (1976) Linear models for evaluating conditional relationships. Am J Polit Sci 2:349-373

$\mathrm{Xu}$ D, Shenkar O (2002) Institutional distance and the multinational enterprise. Acad Manage Rev 27:608-618 